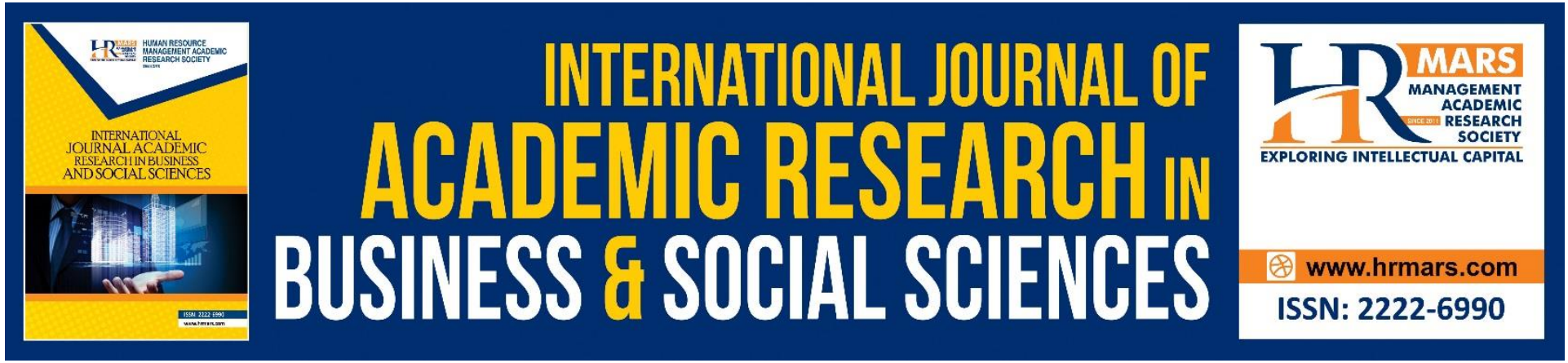

\title{
Effect of Contract Management on Performance of State Corporations in Kenya
}

Gatari Catherine Njoki, Noor Ismail, Anthony Osoro

To Link this Article: http://dx.doi.org/10.6007/IJARBSS/v11-i5/9853 DOI:10.6007/IJARBSS/v11-i5/9853

Received: 03 March 2021, Revised: 07 April 2021, Accepted: 20 April 2021

Published Online: 06 May 2021

In-Text Citation: (Njoki et al., 2021)

To Cite this Article: Njoki, G. C., Ismail, N., \& Osoro, A. (2021). Effect of Contract Management on Performance of State Corporations in Kenya. International Journal of Academic Research in Business and Social Sciences, 11(5), 13-24.

Copyright: @ 2021 The Author(s)

Published by Human Resource Management Academic Research Society (www.hrmars.com)

This article is published under the Creative Commons Attribution (CC BY 4.0) license. Anyone may reproduce, distribute, translate and create derivative works of this article (for both commercial and non-commercial purposes), subject to full attribution to the original publication and authors. The full terms of this license may be seen

at: http://creativecommons.org/licences/by/4.0/legalcode

Vol. 11, No. 5, 2021, Pg. 13 - 24

http://hrmars.com/index.php/pages/detail/IJARBSS

JOURNAL HOMEPAGE

Full Terms \& Conditions of access and use can be found at http://hrmars.com/index.php/pages/detail/publication-ethics 


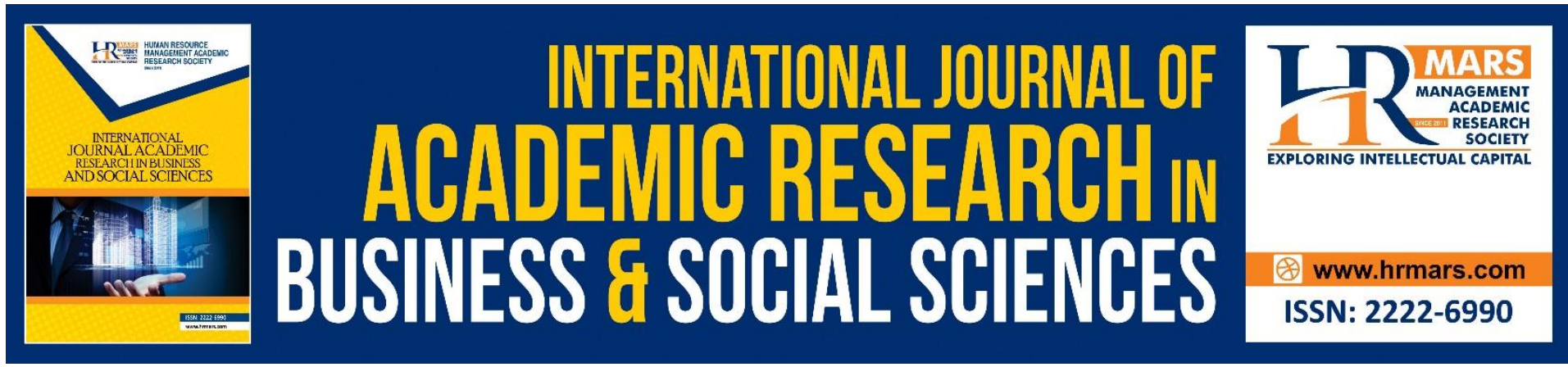

\title{
Effect of Contract Management on Performance of State Corporations in Kenya
}

\author{
Gatari Catherine Njoki \\ PhD Candidate, Jomo Kenyatta University of Agriculture and Technology (JKUAT) \\ Dr. Noor Ismail, PhD, Dr. Anthony Osoro, PhD
}

\begin{abstract}
Contract management is one of the essential aspects of public procurement act that ensures openness, accountability and fair contract administration among state agencies. Despite the emphasis of this aspect in the PPAD Act, very little has been achieved with award of contract being irregular an overpriced as well as unfair distribution of the contracts and tenders in government agencies. This study therefore seeks to establish the influence of contract management on the performance of state corporations in Kenya. A descriptive survey research design was employed in the study with the target population of 187 state corporations in Kenya. A sample size of 374 respondents drawn from 187 state corporations in Kenya was surveyed. A structured questionnaire was used to collect the primary data. The data obtained was analysed using descriptive and inferential statistics through SPSS. The findings revealed that contract management through contract administration, contract monitoring and contract documentation significantly influenced the performance of state corporations. It was concluded that contract management was an essential aspect of PPAD compliance that influenced firm performance hence the recommendation that the management of state agencies should uphold the use of contract management to achieve better performance.
\end{abstract}

Keywords: Contract Management, Public Procurement Act, Firm Performance, State Corporation.

\section{Introduction}

\section{Background of the Study}

Procurement is a critical component in the functioning of any state as it is used for acquiring of assets and services in such a way to meet a specific need. Public Procurement has certainly become gradually more significant factor in economic and business circles worldwide as it has a key responsibility in triumphant management of public resources and most countries have made an attempt to incorporate it into a more strategic view of government hard work (Grandia \& Meehan, 2017). Public procurement of supplies, works and services, is valued to account for $15-20 \%$ of GDP in developing countries, and up to $50 \%$ or more of aggregate state 
expenditure and it is therefore an area that needs attention in the face of increasing noncompliance (Chekol \& Tehulu, 2017).

Contract management is one of the aspects of the public procurement act. It comprises of a set of activities related to contract handling including invitation to and evaluation of bids; awarding and implementation of contracts; measurement, and payment calculation. This also entails monitoring contract associations, handling related issues, integrating essential contract modifications or changes (Nyaga \& Mwangangi, 2019).

Contract management focuses on ensuring that all contacting parties conform to all the terms and conditions of the contract, as well as recording and agreeing with any needed changes in the contract implementation (Nyaga \& Mwangangi, 2019). Since contract management is a procedure, it comprises undertakings required to achieve in order to recognize its benefits. The most important contract management activities include contractor monitoring and acceptance management; managing contract relationships; contract administration; dispute resolution; and contract closure (Eriksson \& Westerberg, 2017). Contractor monitoring and acceptance management is all about making sure that all contracting parties achieve their as per agreed contractual terms. Managing relationships within the contract helps the procuring entity to improve supplier performance through supplier development, early supplier involvement and payment of suppliers on time (Olendo \& Kavale, 2017).

Contract management focuses on keeping an updated contact form, planning and monitoring changes in contract; ensuring that contractor are paid on time; monitoring use of assets; coming up with reports; and use of appropriate procedures in contract termination (Namusonge, 2016). Dispute resolution involved dealing with all conflicts arising from contract through use of the most appropriate conflict resolution methods. Lastly, contract closure occurs after all terms and condition of the contract have been met and achieved by all contracting parties. Proper management of procurement contracts helps an organization to maintain long term relationship with suppliers. This leads to the ability of an organization to acquire quality goods and services, timely delivery, increased revenue and improves customer satisfaction (Aluonzi, Oluka \& Nduhura, 2016).

According to State Corporations Amended Act (2013), a state corporation is a unit which the public has major control over and spends state funds in the acquiring of goods and services for use by the public (RoK, 2013). They are guided by state set of laws and selected bodies such as the State Corporations Advisory Committee (SCAC), and the Efficiency Monitoring Unit. Kenya has 187 state corporations (State Corporations Advisory Committee, 2020).

\section{Statement of the Problem}

The government of Kenya losses about Ksh. 121 billion which is equals to $17 \%$ of the state budget annually which is as a result of inappropriate procurement procedures, lack of proper contract management and poor inventory management procedures (PPRA, 2019; Mugo \& Odari, 2018; King'oo \& Muli, 2019). According to Mutangili, (2019), in 2017/2018 financial year, $32 \%$ of states corporations in Kenya experienced material shortages and $46 \%$ of these entities were still applying traditional methods of inventory records keeping. According to a Public Procurement Regulatory Authority (PPRA) (2019) compliance assessments audit, in the financial year 2017/2018 only 95 out of 187 (50\%) state corporations submitted their procurement reports as required by the public procurement Act. The audit report indicated that these 95 state corporations had an aggregate compliant score of $45.5 \%$ for the period, this being below the threshold of $50 \%$ (Rono \& Moronge, 2019). Available evidence shows that failure to comply with the Public Procurement Act among the state corporations continue 
to cost the taxpayers billions of shillings due to poor inventory optimization (Jepchirchir \& Noor, 2019). Empirical studies have shown mixed results on the relationship between compliance with public procurement Act and organizational performance. Despite this, there exists scarce evidence on the role played by contract management as one of the aspects PPDA compliance on performance of state corporations. This study therefore sought to bridge the existing gaps by assessing the effect of contract management on performance of state corporations in Kenya.

\section{Objectives of the Study}

1. To establish the effect of contract management on performance of state corporations in Kenya.

2. To analyze the moderating effect of enforcement on the relationship between contract management and performance of state corporations in Kenya.

\section{Research Hypothesis}

1. $H_{0}$ : Contract management does not significantly affect performance of state corporations in Kenya.

2. $H_{0}$ : There is no significant moderating effect of enforcement on the relationship between contract management and performance of state corporations in Kenya.

\section{Literature Review \\ Theory of Public Contracts}

Theory of public contracts was developed by Spiller (2008) to analyze how public procuring entities create and improve legal contracts. This theory is considered to be relevant for this study in order to understand the effect of contract management on performance of state corporations hence it gives theoretical background of this study. It evaluates how parties with contradictory interests develop formal and informal contracts through agreements (Spiller, 2008). The theory indicates that public procurement contracts appear to be characterized by formal, consistent, bureaucratic, inflexible processes. Public contracts are commonly seen to more rigid, necessitating regular formal renegotiation, with greater propensity to litigate, and giving weaker incentives (Tan \& Lee, 2015).

\section{Contract Management}

Contract management entails three various aspects; realization of the three goals of product quality, timely delivery and in line with the budget (Aluonzi et al., 2017). Contract management is divided into upstream and downstream supply chain activities that requires proper monitoring, establishments of collaborative buyer supplier relationships, proper reporting on contract progress, and management of contracts variations and conflicts managements. Oliveira (2016) in a study on the construction agreements management in South Africa, the study findings indicated that poor contract management leads loss of income generated from a successful contract. The study also indicated that that poorly managed contracts affect the procuring entity's trustworthiness through a snowball effect. This suggests the trouble to internally sell and enforce future contracts. Therefore, it is important for an entity to outline its prospects evidently in the contract. The entity needs should be well recorded and that employees in all management levels and users need to be involved in the establishment of specifications and keeping record (Oliveira, 2016). 
Nyaga and Mwangangi, (2019) carried out a study on the influence of contract management practices on performance of public sector in Kenya. The findings of the study indicated that procurement regulators admitted that many PEs were not managing their contracts properly and among areas of concern included failure to appoint inspection and acceptance committees to inspect delivery of goods so as to ascertain quantity and quality as per contract requirements. They pointed out that in works procurement contracts where more funds were normally committed relative to goods and services, works supervisors to oversee the implementation of construction works were not appointed. Kimundu and Moronge, (2019) carried out a research on Influence of contract management on procurement performance in manufacturing firms of Kenya. The findings of the study indicated that procurement contracts performance indicators involves attainment of value for money, quality products and services, reduced lead time, procurement contracts cost reduction, timely contract closure and termination. The study also noted that for a successful contract management the contracting parties should consider; appropriate contract administration, management of service and products delivery, managing relationships with suppliers, conflict resolutions, contract monitoring and effective contract termination procedures in line with public procurement Act.

\section{Conceptual Framework}

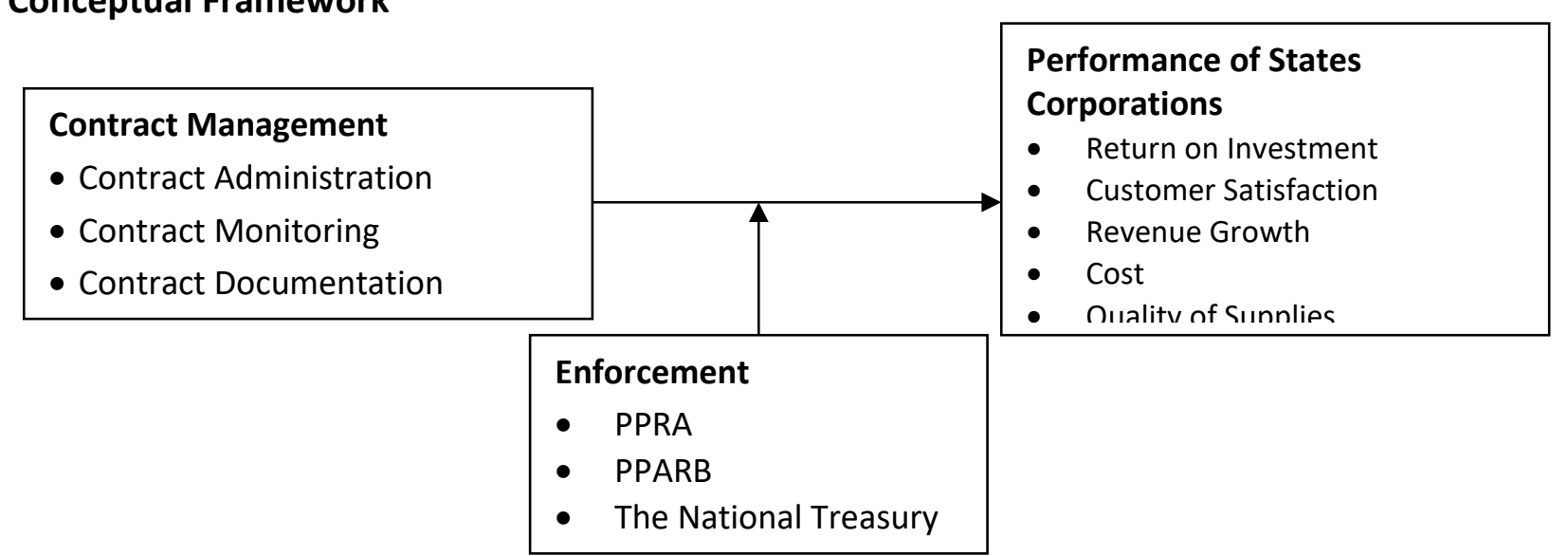

Independent Variables

Moderating Variable

Dependent Variable

Figure 1: Conceptual Framework

\section{Research Methodology}

Descriptive research design was employed in this study. Descriptive study design was ideal for this study because it describes data and characteristics about the population or phenomenon under study.

The target population for this study included all registered state corporations in Kenya. These are the companies owned by the Kenyan Government. According to GOK (2018) there are 187 States Corporations in Kenya. The study unit of analysis will be all 187 state corporations in Kenya and the unit of observation will be each head of finance and the head of procurement function in all 187 states corporations in Kenya which formed 374 respondents.

The study used a census which comprised of each head of finance and the head of procurement function in all 187 states corporations in Kenya which formed 374 respondents. The study used a census to obtain the units of analysis and purposive Sampling to identify the 
units of observation. The head of finance and the head of procurement function were selected purposively because they have similar skills, knowledge, experience and exposure in the area of research.

A questionnaire was used to collect data. The questionnaire was administered through online platforms due to the implications of COVID-19 and the locale of some of the state corporations as way of saving costs and time.

Quantitative data was analyzed using descriptive and inferential statistics. Descriptive statistics using the mean, median and standard deviation and, inferential statistics that involved correlation and regression analysis were applied to analyze quantitative data. This was made possible through the use of Statistical Package for Social Sciences (SPSS).

A multiple linear regression analysis was used to establish a mathematical model that explains the link involving the dependent variable and the significant independent variables previously shown through correlation analysis.. The following summary of a multiple linear regression model was applied to model the data:

$Y=\beta_{0}+\beta_{1} X_{1}+\varepsilon$

Where,

$\beta_{0}=$ constant

$\beta_{1}$ is the coefficient for $X_{i}$

$Y=$ Performance of State Corporations

$\mathrm{X}_{1}=$ Contract Management

\section{Research Findings}

\section{Contract Management}

The study sought to assess the influence of contract management on the performance of state corporations in Kenya. The study sought to establish the contract administration, contract monitoring and contract documentation as the main aspects of contract management on the performance of state corporations. The findings revealed that contract administration as an aspect of contract management is not effectively done as required by the act hence putting most of the state corporations at the edge of losing their collaboration and trust with the suppliers. Kibogo and Mwangangi, (2017) observed that contract management in cases where payments are not done on time and proper adherence to the agreement terms affects the relationship between the supplier and the organization and this puts the customers at the helm of dissatisfaction.

Documentation in the contract management process in most of the surveyed state corporations was keenly upheld but the relationship between the suppliers/contractors and the corporations was poor and little strategies were taken to enhance this relationship. The findings concur with those by Abdullahi, Ibrahim, Ibrahim, and Bala (2019) who found out that while most of the organizations especially in the public sector would be keen on adhering to the process of contract management as the law provides, their commitment towards having the best contractor and maintaining such contracts is inadequate. According to Rajab (2018), the process of tendering and contract management is a vital process as far as organizational performance is concerned hence it should be upheld on the basis of having the best contractor and having such contractors on board for future reference. 
Table 1: Descriptive Statistics on Contract Management

\begin{tabular}{|c|c|c|c|}
\hline \multirow[t]{2}{*}{ Statement } & \multirow[t]{2}{*}{$\mathbf{N}$} & \multicolumn{2}{|c|}{ Mea Std. } \\
\hline & & & Dev. \\
\hline All formed contract are in written signed contract form & 304 & 3.13 & 1.32 \\
\hline The contractors in our organization are always paid on time & 304 & 3.05 & 1.08 \\
\hline $\begin{array}{l}\text { Any variation of a contract is considered after twelve months from the date } c \\
\text { signing the contract }\end{array}$ & $f 304$ & 3.85 & 0.88 \\
\hline $\begin{array}{l}\text { There is regular monitoring of the contracts to ensure that all delivery c } \\
\text { performance obligations are met }\end{array}$ & r304 & 3.84 & 1.03 \\
\hline $\begin{array}{l}\text { The organization upholds strategies to enhance positive relationship with th } \\
\text { contractors }\end{array}$ & e304 & 3.63 & 1.15 \\
\hline There is regular maintenance of an updated form of the contract and reportin & g304 & 3.54 & 1.19 \\
\hline The organization keeps comprehensive contract records & 304 & 3.47 & 1.14 \\
\hline $\begin{array}{l}\text { All contractors submit the required documentation as specified in th } \\
\text { tendering documents }\end{array}$ & e304 & 3.39 & 1.25 \\
\hline All contract documents are made clear to all parties involved in the contract & 304 & 3.69 & 1.08 \\
\hline
\end{tabular}

The findings as shown in Figure 2 revealed that majority of the respondents (51.9\%) felt that contract management effectively contribute to the performance of their respective state corporations. One the other hand, $39.2 \%$ indicated that the contract management had ineffective influence on the performance of their respective corporations. The findings imply that while majority of the respondents feel that the contract management as constituted influenced the performance of the state corporations, a significant number did not see any influence of contract management on performance an indication that the corporations ought to improve on their prospects of contract management of this was to enhance their performance.

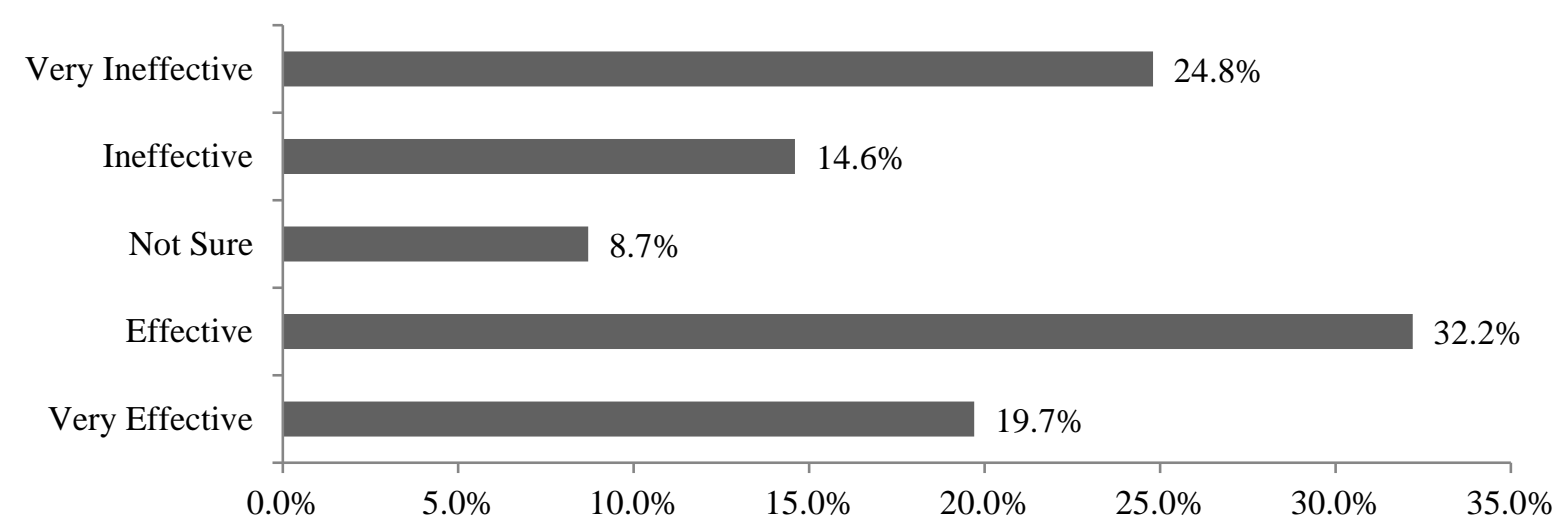

Figure 2: Rating the Effectiveness of Contract Management

\section{PPDA Enforcement}

The study sought to assess the moderating effect of the enforcement of the PPDA act on the relationship between contract management and the performance of state corporations in Kenya. The main aspects used to assess the enforcement were: the public procurement regulatory author, the public procurement administrative review board and the national treasury. The results are as summarized in Table 2 . The findings imply that while some of the authorities set aside to enforce the compliance of the PPDA have not effectively carried out their mandate and this could affect the compliance rates among the state corporations. 
Table 4.1: Descriptive Statistics on PPDA Enforcement

\begin{tabular}{|c|c|}
\hline Statement & $\begin{array}{l}\text { nStd. } \\
\text { Dev. }\end{array}$ \\
\hline $\begin{array}{l}\text { The National Treasury always provide technical assistance on } 3043.10 \\
\text { implementation and operation of the Act }\end{array}$ & 1.01 \\
\hline $\begin{array}{l}\text { The national treasury regularly issue guidelines to our entity with respect to } 3043.00 \\
\text { all procurement matters }\end{array}$ & 1.07 \\
\hline $\begin{array}{l}\text { he national treasury always formulate and promote asset disposal policy } 3043.11 \\
\text { nd standards to improve compliance }\end{array}$ & 1.87 \\
\hline $\begin{array}{l}\text { DRA always monitor, assess and review our public procurement and asset } 3043.47 \\
\text { sposal activities }\end{array}$ & 1.06 \\
\hline $\begin{array}{l}\text { PRA regularly monitor the implementation of the preference and } 3044.07 \\
\text { eservation schemes in our procurement activities }\end{array}$ & 0.86 \\
\hline $\begin{array}{l}\text { PPRA regularly carryout compliance audits of our procurement processes to } 3043.35 \\
\text { enforce compliance }\end{array}$ & 1.17 \\
\hline $\begin{array}{l}\text { PPARB ensures that all tendering and assets disposal disputes are } 3043.10 \\
\text { investigated }\end{array}$ & 1.06 \\
\hline $\begin{array}{l}\text { PPARB ensures that all procurement related cases are reviewed and } 3043.15 \\
\text { determined on time }\end{array}$ & 1.78 \\
\hline $\begin{array}{l}\text { PPARB ensures that all procurement related cases are handled and finalized } 3043.00 \\
\text { within required time }\end{array}$ & 1.79 \\
\hline
\end{tabular}

\section{Performance of State Corporations in Kenya}

The study sought to assess the performance of state corporation in relation to the compliance with the public procurement act on contract management. The findings as shown in Figure 3 revealed that the overall score was at $26.7 \%$ while quality of supplies had the highest score with $43 \%$. Return on investment and return on assets had scores of $14.6 \%$ and $18.4 \%$ respectively while revenue growth had a score of $19.8 \%$. According to the International Procurement Agency, the global average performance rate in public entities in relation to procurement laws and policy compliance is $43.5 \%$. This is too high than the Kenya's average of $26.7 \%$ observed in the study hence the need for improvement in compliance with the PPDA among the state corporations.

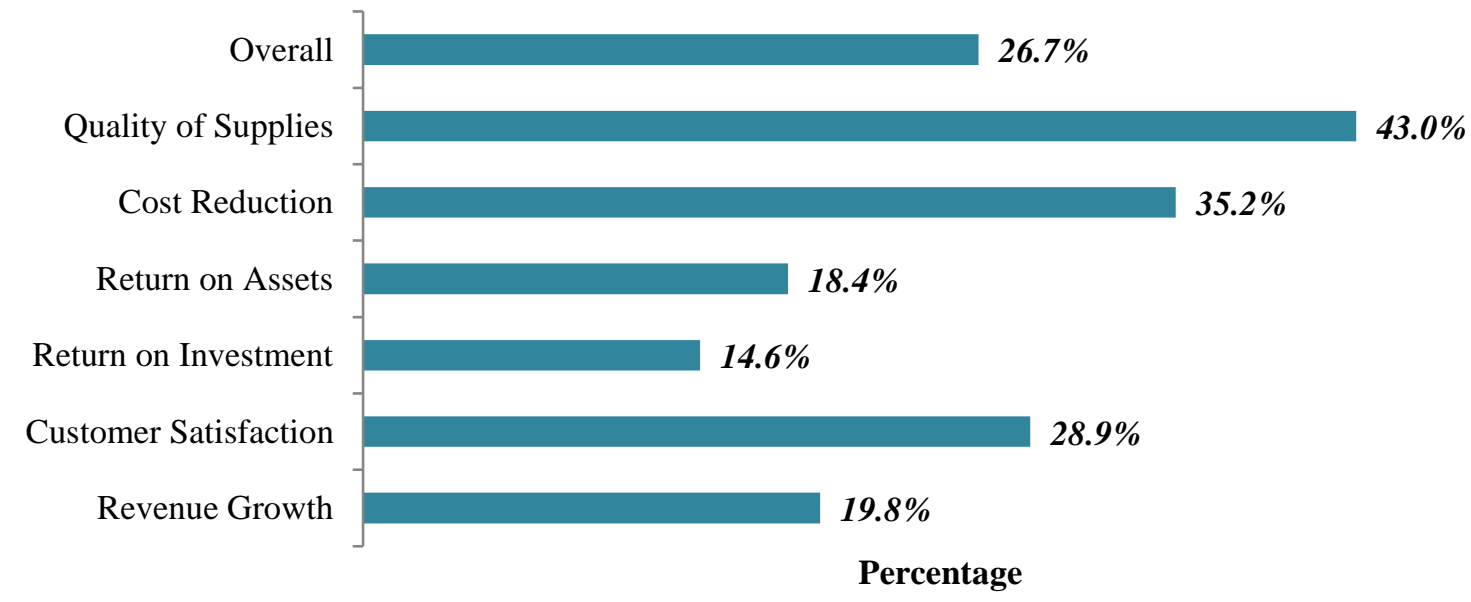

Figure 3: Rating the Aspects of Performance 


\section{Test of Hypothesis}

$H_{o}$ : Contract management does not significantly affect performance of state corporations in Kenya

The second objective of the study was to assess the influence of contract management on performance of state corporations in Kenya. The study sought to establish the statistical relationship between contract management and the performance of state corporations in Kenya. This was done using ANOVA, regression coefficients and the scatter plot diagram. The proposed model for the variable was; $Y=\beta_{0}+\beta_{2} X_{2}$.

The model summary shown in Table 3 revealed that the $R$ value for the model was 0.680 and the $R^{2}$ was 0.462 , an indication that a variability of $46.2 \%$ in firm performance could be explained by a unit change in contract management. The model thus was deemed appropriate to explain the relationship between contract management and the performance of state corporations in Kenya.

Table 3: Model Summary (Contract Management)

\begin{tabular}{llllll}
\hline Model & $\mathrm{R}$ & R Square & Adjusted R Square & $\begin{array}{l}\text { Std. Error of the } \\
\text { Estimate }\end{array}$ & \\
\hline 1 & $.680^{\mathrm{a}}$ & .462 & .460 & .53628 & \\
\hline
\end{tabular}

a. Predictors: (Constant), Contract Management

b. Dependent Variable: Performance of State Corporations

The ANOVA results are as shown in Table 4 which revealed that at the F-calculated value of 259.511 and the mean of 74.636 indicates the model was significant at a p-value of 0.000 less than the standard $p$-value of 0.05 . This implies that the variable contract management was significant and the model could statistically significantly predict the relationship between contract management and performance of state corporations in Kenya.

Table 4: ANOVA Test

\begin{tabular}{lllllll}
\hline Model & & Sum of Squares & $\mathrm{df}$ & Mean Square & $\mathrm{F}$ & Sig. \\
\hline \multirow{2}{*}{1} & Regression & 74.636 & 1 & 74.636 & 259.511 & $.000^{\mathrm{b}}$ \\
& Residual & 86.856 & 302 & .288 & & \\
& Total & 161.492 & 303 & & & \\
\hline
\end{tabular}

a. Dependent Variable: Performance of State Corporations

b. Predictors: (Constant), Contract Management

The coefficient results shown in Table 5 revealed that the $\beta$ for the contract management was

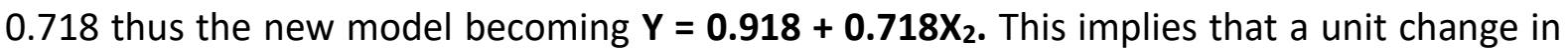
contract management could explain up to $71.8 \%$ change in the performance of state corporations in Kenya. The P-value for the variable was $0.000<0.05$, an indication that contract management had a positive and significant influence on performance of state corporations in Kenya. 
Table 5: Regression Coefficients

\begin{tabular}{|c|c|c|c|c|c|c|}
\hline \multirow[t]{2}{*}{ Model } & & \multicolumn{2}{|c|}{$\begin{array}{l}\text { Unstandardized } \\
\text { Coefficients }\end{array}$} & \multirow{2}{*}{$\begin{array}{l}\text { Standardized } \\
\text { Coefficients } \\
\text { Beta }\end{array}$} & \multirow[t]{2}{*}{$\mathrm{t}$} & \multirow[t]{2}{*}{ Sig. } \\
\hline & & $B$ & Std. Error & & & \\
\hline & (Constant) & .918 & .161 & & 5.690 & .000 \\
\hline 1 & $\begin{array}{l}\text { Contract } \\
\text { Management }\end{array}$ & .718 & .045 & .680 & 16.109 & .000 \\
\hline
\end{tabular}

a. Dependent Variable: Performance of State Corporations

$H_{o}$ : There is no significant moderating effect of enforcement on the relationship between contract management and performance of state corporations in Kenya.

The regression coefficients for the moderated model are as shown in Table 6 . As the results portray, only the interaction between contract management and PPDA enforcement were significant $(P<0.05)$ implying that PPDA enforcement had a moderating effect on the relationship between contract management and performance of state corporations in Kenya. The null hypothesis was therefore rejected.

Table 6: Regression Coefficients

\begin{tabular}{lllllll}
\hline Model & \multicolumn{2}{l}{$\begin{array}{l}\text { Unstandardized } \\
\text { Coefficients }\end{array}$} & \multicolumn{2}{l}{$\begin{array}{l}\text { Standardized t } \\
\text { Coefficients }\end{array}$} & Sig. \\
& B & Std. Error & Beta & \\
\hline 1 & (Constant) & 1.509 & .118 & & 12.783 & .000 \\
& Contract Management*PPDA Enforcement .076 & .017 & .376 & 4.568 & .000 \\
\hline
\end{tabular}

a. Dependent Variable: Performance of State Corporations

\section{Conclusion and Recommendations}

The study concluded that while contract management was recognized as a key enabler to the performance of the stat corporations, it was not effectively upheld among the organizations. The study concluded that indeed, contract management had a significant influence on the performance of state corporations. It was however noted that the administration of contracts and monitoring the contractors for efficient delivery was not sufficiently undertaken and this could affect the anticipated results of the entire contract management process. Implementation of the PPAD requires that proper documentation is upheld as well as efficiency in management the relationship between the organization and the suppliers. This being not equitably upheld means poor performance of the state corporations as far as compliance with the PPAD is concerned.

The government through the appropriate regulatory agencies has the mandate to ensure that proper monitoring is done on the way contracts are managed in state corporations as a way of ensuring accountability and fairness in the entire process. The management of the corporations should also be at the forefront of ensuring that there is proper documentation of the contracts and that the contracts are efficiently and keenly administered for adequate adherence to the procedures and guidelines. The state regulatory agencies such as the PPRA and the PPARB should be at the forefront of ensuring the contract management at the state corporations is as provided under the Act through ensuring that all formed contract are signed by contracting parties, all contractors are paid on time, regular maintenance of an updated form of the contract and submitting annual reports on all procurement activities and ensuring that there is maintenance of positive relationship with the contractors for mutual benefits. 
This study has contributed to the existing knowledge by showing the role played by contract management as an aspect of public procurement and assets disposal act implementation on the performance of state corporations in Kenya. The study has filled the existing gaps by giving a more recent literature on the relationship between contract management and performance of public-owned organizations, in a Kenyan context. The study has also contributed to the existing theory by showing the relevance of theory of public contracts in addressing contract management. The study has proved the role of aspects pointed out in the public contracts theory in enhancing the effectiveness of procurement process and increasing firm performance.

\section{References}

Abdullahi, B., Ibrahim, Y. M., Ibrahim, A. D., \& Bala, K. (2019). Development of web-based eTendering system for Nigerian public procuring entities. International Journal of Construction Management, 1-14.

Aluonzi, G., Oluka, P., \& Nduhura, A. (2016). Contract Management and Performance of oad Maintenance Projects: The Case of Arua Municipality. Universal Journal of Management, 4(10), 550-558.

Chekol, G. A., \& Tehulu, T. A. (2017). Public procurement reform in Ethiopia: Factors leading to effective public procurement implementation: The case of Amhara Region: European Journal of Business and Management, 6 (23), 153-158.

Eriksson, P. E., \& Westerberg, M. (2017). Effects of procurement on construction project performance. In International Conference on Management of Technology, 5(9)

Grandia, J., \& Meehan, J. (2017). Public procurement as a policy tool: using procurement to reach desired outcomes in society. International Journal of Public Sector Management, 30(4), 302-309

Jepchirchir, J., \& Noor, I. (2019). Effects of inventory optimization on performance of government ministries in Kenya. The Strategic Journal of Business \& Change Management, 6 (4), $142-160$.

Kibogo, A. D., \&Mwangangi, M. (2017). Factors Affecting Contract Management in Public Procurement Sector in Kenya: A case of Kenya Literature Bureau. European Journal of Business Management, 1(110,377-384.

Kimundu, G. N., \& Moronge, M. (2019). Influence of contract management on procurement performance in manufacturing firms of Kenya; A case Bidco Oil Refineries Ltd. The Strategic Journal of Business \& Change Management, 6 (1), $106-120$.

King'oo, D. M., \& Muli, S. (2019). Influence of procurement practices on organizational performance in Kenyan Public Sector. A case of Ministry of Education. The Strategic Journal of Business \& Change Management, 6 (2), 2400 - 2412.

Mugo, R., \& Odari, S., (2018). Factors Affecting Procurement Performance in Mobile Telecommunications Original Equipment Manufacturers: A Case Study of Ericsson Kenya Limited. International Journal of Recent Research in Social Sciences and Humanities (IJRRSSH), Vol. 5, Issue 4, pp: 233-239.

Mutangili, S. K. (2019). Effects of Procurement Law on Procurement Performance: A Case of Kenya National Highway Authority. Journal of procurement \& Supply Chain, Vol 3 No 1.

Mwangi, P. N., Karanja, N., \& Namusonge, G. (2017). Determinants of Compliance with Access to Government Procurement Opportunities (AGPO) Regulations for Special Groups by 
Public Universities in Kenya. International Journal of Business \& Law Research,5(2):111, ISSN: $2360-8986$

Namusonge, G. (2016). The Effect of Monitoring, Evaluation and Risk Management of Projects on Performance of Firms in the Telecommunication Sector In Kenya. Strategic Journal of Business \& Change Management, Vol 3, No 4.

Namusonge, S. O., Mukulu, E., \& Kirima, N. (2016). Role of collaborative planning, forecasting \& replenishment on hotel performance as mediated by cooperative behaviour: A survey of the kenyan hospitality industry, International Journal of Current Research, Vol. 7, Issue, 09, pp.20448-20458.

Ngeno, K. J., Namusonge, G. S., \& Nteere, K. K. (2016). Effect of discriminatory public procurement practices on organizational performance: A survey of public sector corporations in Kenya: Global Journal of Commerce and Management Perspective, 3(4), 245- 256.

Nyaga, M. M., \& Mwangangi, P. (2019). Influence of contract management practices on performance of Kiambu County. The Strategic Journal of Business \& Change Management, 6 (1), $661-675$.

Olendo, J. A., \& Kavale, S. (2017). Effects of Supplier Relationship Management on Supply Chain Performance at Bamburi Cement Mombasa, Kenya. The International Journal of Business \& Management, 4 (7) $436-452$

Oliveira, M. (2016).The Management of Construction Agreements in South Africa. Retrieved from https://www.irbnet.de/daten/iconda/CIB_DC24517.pdf

Public Procurement and Asset Disposal Act. (2015). Public Procurement and Asset Disposal Act, 2015, Nairobi: Public Procurement and Asset Disposal

Rajab, N. F. (2018). Effect of Regulated Electronic Tendering Practices on the Implementation of Preference Regulations in Kenyan State Corporations. Journal of Supply Chain Management Systems, 7(1).

Republic of Kenya. (2013). Report of the presidential taskforce on parastatals reform. Nairobi: Government Press.

Republic of Kenya. (2015). Public Procurement and Assets Disposal General Manual, PPAD Act, Nairobi. Government Press.

Rono, A. K., \& Moronge, M. (2019). Determinants of implementation of procurement management practices in county governments of Kenya: a case of Nairobi County. The Strategic Journal of Business \& Change Management, 6 (2), 160 - 172.

Spiller, T. (2008). An Institutional Theory of Public Contracts: Regulatory Implications (August 2008). NBER Working Paper No. w14152, Available at SSRN: $h$ ttps://ssrn.com/abstract $=1231682$

Tan, J. K., \& Lee, R. (2015). An agency theory scale for financial services. Journal of Services Marketing, 29(5), 393-405. 